\title{
Erratum to: Influence of Cyclic Straining on Fatigue, Deformation, and Fracture Behavior of High-Strength Alloy Steel
}

K. Manigandan, T.S. Srivatsan, V.K. Vasudevan, D. Tammana, and B. Poorganji

\section{Erratum to: JMEPEG DOI 10.1007/s11665-015-}

\section{6-2}

Please note that the correct spelling of the surname of fifth author of this article is "Poorganji" (not "Poorbangi").

The online version of the original article can be found under doi:10.1007/s11665-015-1736-2.

K. Manigandan and T.S. Srivatsan, Department of Mechanical Engineering, The University of Akron, Akron, OH 44325-3903; and V.K. Vasudevan, D. Tammana, and B. Poorganji, School of Dynamic Systems, Materials Science and Engineering Program, University of Cincinnati, Cincinnati, $\mathrm{OH}$ 45221-0072. Contact e-mails: tss1@uakron.edu and vasudevk@ucmail.uc.edu. 